\title{
Sweet-P inhibition of glucocorticoid receptor $\beta$ as a potential cancer therapy
}

\author{
Assumpta C. Nwaneri ${ }^{\star}$, Lucien McBeth ${ }^{\star}$, and Terry D. Hinds Jr. \\ Center for Hypertension and Personalized Medicine, Department of Physiology \& Pharmacology, \\ University of Toledo College of Medicine, Toledo OH 43614, USA
}

\section{Abstract}

The need for the development of new cancer therapies and push for the design of new targeting techniques is on the rise, and would be useful for cancers that are resistant to current drug treatments. The understanding of the genome has significantly advanced cancer therapy, as well as prevention and earlier detection. This research highlight discusses a potential new type of cancertargeting molecule, Sweet-P, which is the first of its kind. Sweet-P specifically targets the microRNA-144 binding site in the $3^{\prime}$ untranslated region ( $3^{\prime}$ UTR) of the human glucocorticoid receptor $\beta(\operatorname{GR} \beta)$, which has been demonstrated to increase expression. GR $\beta$ has been shown to be highly expressed in cells from solid tumors of uroepithelial carcinomas, gliomas, osteosarcomas, and hepatocellular carcinomas, as well as in liquid tumor cells from leukemia patients. In noncancerous diseases, GR $\beta$ has been shown to be highly expressed in glucocorticoid-resistant asthma. These maladies brought the need for the development of the Sweet-P anti-GR $\beta$ molecule. Sweet-P was shown to repress the migration of bladder cancer cells, and may serve as a new therapeutic for GR $\beta$-related diseases.

\section{Keywords}

Glucocorticoid receptor; GR; GR alpha; GR beta; glucocorticoids; cancer; bladder cancer; asthma; growth; migration; microRNA; miRNA; Sweet-P

In our recent work, published in Oncotarget, we have discovered that the glucocorticoid receptor $\beta$ (GR $\beta)$ causes migration (movement) of human bladder cancer cells ${ }^{[1]}$. Bladder cancer is the $4^{\text {th }}$ most common cancer in men, and the $5^{\text {th }}$ most overall ${ }^{[2]}$. Almost threequarters of bladder cancer patients may have a recurrence, and one-third experience progression, causing the need for constant lifelong surveillance and treatment ${ }^{[3]}$. The longterm therapy results in bladder cancer being the most costly cancer for lifetime regimen ${ }^{[4]}$,

Licensed under a Creative Commons Attribution 4.0 International License which allows users including authors of articles to copy and redistribute the material in any medium or format, in addition to remix, transform, and build upon the material for any purpose, even commercially, as long as the author and original source are properly cited or credited.

Correspondence: Terry D. Hinds, Jr. Terry.Hinds@utoledo.edu.

These authors contributed equally

Conflicting interests

The authors have declared that no conflict of interests exist.

The content is solely the responsibility of the authors and does not necessarily represent the official views of the National Institutes of Health. 
which brings the need for new and better treatments. Because we showed that GR $\beta$ plays a role in bladder cancer migration, we set out to construct the first anti-GR $\beta$ molecule, which we termed Sweet-P, with the goal of providing a potential new therapy. Sweet-P was designed as a peptide nucleic acid (PNA), conjugated to the Trans-Activator of Transcription (TAT) protein from HIV (for cellular delivery) to specifically target the $3^{\prime}$ untranslated region ( $3^{\prime}$ UTR) of human GR $\beta$. Sweet-P functions by specifically blocking the microRNA-144 (miR-144) binding site in the $3^{\prime}$ UTR of human GR $\beta$ (Figure 1), which we showed increases expression. Furthermore, Sweet-P and shRNA suppression of GR $\beta$ in human bladder cancer cells attenuated migration ${ }^{[1]}$.

The gene that codes for GR in humans is found on the $q$ arm of chromosome $5^{[5,6]}$, and is a single GR gene that is alternative spliced to give rise to at least five isoforms $\mathrm{a}, \beta, \gamma, \mathrm{A}$, and $\mathrm{P}^{[5,7-9]}$. GRa and GR $\beta$ have been the most investigated isoforms. GRa is identical to GR $\beta$ from exons $2-8$ and is distinguished by alternative splicing of exon 9 in humans resulting in the differing of the C-terminus ${ }^{[10]}$. GRa contains an additional fifty amino acids derived from the proximal portion of exon 9 that constructs helix 12 for ligand binding. GR $\beta$ does not have the capacity to bind glucocorticoids because of an additional fifteen amino acids derived from the distal portion of exon 9 that causes a degenerate helix $12{ }^{[5,9,11,12]}$. The alternative splicing mechanism in humans is different than in mouse ${ }^{[11]}$, rat ${ }^{[13]}$, and zebrafish ${ }^{[14]}$, but in these species that GR $\beta$ has been identified, GRa and GR $\beta$ are identical through exon 8 with an addition of an alternatively spliced intron 8 . In humans, the $3^{\prime}$ UTR of GR $\beta$ and GRa are different ${ }^{[10]}$ and are targeted differently by miRNAs. For instance, miR-144 increased GR $\beta$ but had no effect on GRa expression in human bladder cancer cells ${ }^{[1]}$. However, GC resistance in sepsis is influenced by miR-124, which downregulated GRa ${ }^{[15]}$. The effect of miR-124 on GR $\beta$ is unknown and miRNAs that target GR $\beta$ or GRa are very limited.

GR $\beta$ has been shown to antagonize GRa, which has been demonstrated to be due to the competition with GRa for glucocorticoid response elements (GREs)/coregulators, coactivator squelching through the transactivation domain, and through inactive $\alpha / \beta$ dimers that bind in the nucleus $[6,11,16,17]$. Therefore, increasing GR $\beta$ levels can lead to a GCresistant state that allows for an elevation of proinflammatory cytokines and transcription factors ${ }^{[10,11,18-20]}$. The ratio of GRa:GR $\beta$ is a critical factor in GC disease states $[10,17,18,20]$. A high GRa:GR $\beta$ ratio can be indicative of a GC-sensitive state while a low ratio would be considered GC-resistant ${ }^{[18]}$. Importantly, Sweet-P inhibition of GR $\beta$ increased the responsiveness to GCs ${ }^{[1]}$, which indicates that it may reverse GR $\beta$ induced GC-resistant diseases. Also, GR $\beta$ has recently been shown to have positive and negative GRa independent transcriptional activity ${ }^{[6,12]}$. We recently demonstrated that mouse GR $\beta$ specifically binds to the promoter of phosphatase and tensin homolog (PTEN), which increased Akt1 guided proliferation ${ }^{[21]}$. We also showed that Sweet-P inhibition of human GR $\beta$ increased PTEN expression in bladder cancer cells ${ }^{[1]}$ (Figure 1). There may be other GR $\beta$-specific gene targets that are increased in cancer, and microarray or RNA-seq studies would help strengthen our understanding of the involvement of GR $\beta$ in cancer. However, this work is yet to be done. 
Sweet-P may have several clinical applications as GR $\beta$ has been shown to be involved in other cancer types. For example, treatment with GCs as a first line therapy in acute lymphoblastic leukemia (ALL) is effective due to its ability to arrest cell growth and trigger apoptosis. Unfortunately, resistance to therapeutic GCs is common, which has been attributed to increased levels of GR $\beta$ or decreased GRa ${ }^{[22]}$. The GR $\beta$ interaction with $\beta$ catenin and transcription factor-4 (TCF-4) was shown to positively regulate astrocyte activity, leading to increased proliferation ${ }^{[23,24]}$. This observation further supports our previous finding of GR $\beta$ stimulation of growth ${ }^{[21]}$, albeit via Akt1 activation and PTEN inhibition. Also, GR $\beta$ was shown to increase migration of glioblastoma cells ${ }^{[25]}$. However, the interaction of miR-144 with the GR $\beta$ 3'UTR in glioblastoma or ALL is unknown. In LNCaP-ARA70 $\beta$ prostate cancer cells, which express increased levels of GR $\beta$, Ligr et al. reported increased cellular growth and proliferation ${ }^{[26]}$. Furthermore, treatment with methotrexate in peripheral mononuclear and lymphocyte cells resulted in decreased GR $\beta$ expression, thus increasing GC sensitivity ${ }^{[27]}$. Additionally, Piotrowska et al. demonstrated in Hut-78 and Raji B-lymphoma cells, MCF-7 breast cancer cells, and HT-29 colon carcinoma cells that known growth inhibitors trichostatin, sodium butyrate, and 5-Aza-20deoxycytidine treatment suppressed GR $\beta$ and enhanced GRa with an increase in GC sensitivity ${ }^{[28,29]}$. However, miR-144 levels, proliferation, or migration were not assessed in these studies. Nevertheless, these observations indicate the necessity of developing an antiGR $\beta$ therapy to specifically target GR $\beta$-related cancers.

In non-cancerous diseases, the resistance to GCs due to high levels of GR $\beta$ have been reported, and Sweet-P can potentially be used as a novel therapy. Most clinically relevant is the anti-inflammatory and immunosuppressant effects of GCs, which have been shown to decrease levels of cytokines, chemokines, and vasoactive agents. GCs reduce the movement of leukocytes to inflamed areas, and the function of immunocompetent cells ${ }^{[8]}$. In mice, increased GC levels induce apoptosis in thymocytes ${ }^{[30]}$. Because of the anti-inflammatory effects of GCs, they are commonly prescribed to asthma patients. Many studies have demonstrated an elevated expression of GR $\beta$ and GC-insensitivity in the airways of asthma patients ${ }^{[31-34]}$. Christodoulopoulos et al. showed that approximately $8 \%$ of cells in large and $2 \%$ of cells in small airways of patients were GR $\beta$ positive. However, mild asthma patients had an increase of $14 \%$ ( 7 fold) in GR $\beta$ positive cells in the small airways, but no change in expression in large airways. Alarmingly, in fatal asthmatic patients, the airways showed a dramatic increase in GR $\beta$ positive cells to $21 \%$ ( 2.5 fold) in large and 35\% (17 fold) in small airways ${ }^{[31]}$. Hamid et al. reported an increased number of GR $\beta$ immunoreactive inflammatory cells in the airway T-cells of GC-resistance patients when compared to GC-sensitive or healthy patients ${ }^{[33]}$. In tuberculin-driven cutaneous inflammatory lesions of patients with GC-resistance asthma, increased number of cells expressing GR $\beta$ was also reported ${ }^{[34]}$. Furthermore, Goleva et al. demonstrated in bronchoalveolar lavage macrophages that GC-insensitive asthmatics have elevated GR $\beta$ mRNA and protein levels in comparison to GC-sensitive patients ${ }^{[32]}$. Of most interest, the authors reported enhancement of dexamethasone-induced GRa transactivation in GCinsensitive asthmatics after RNAi silencing of GR $\beta$. As such, Sweet-P suppression of GR $\beta$ may serve useful for GC-insensitive asthmatic patients. 
Our work highlights miR-144's role in inducing migration of bladder cancer cells via GR $\beta$; however, miR-144 has been demonstrated to play roles, both positive and negative, in many other forms of cancers and diseases. For example, miR-144 has been shown to contribute to the pathogenesis of Alzheimer's disease through the downregulation of ADAM10 ${ }^{[35]}$ but is essential for proper erythropoiesis by downregulating RAB14 [36]. Also, miR-144 has been shown to promote nasopharyngeal carcinoma through the downregulation of PTEN, a regulator of the PI3K/AKT pathway ${ }^{[37]}$, and induce breast cancer and hepatocarcinoma cell proliferation through the downregulation of Runx1, a tumor-suppressor gene [38]. Interestingly, estrogen treatment (E2) in $\mathrm{SkBr} 3$ breast cancer and HepG2 hepatocarcinoma cells increased the expression of miR-144 through the PI3K/ERK/Elk1 transduction pathway ${ }^{[39]}$, which may serve as a positive activator of GR $\beta$. Solakidi et al. showed in HepG 2 and SaOS-2 cells that GR $\beta$ and ERa were localized mainly in the nucleus, particularly concentrated in nuclear structures which suggest a direct involvement of GR $\beta$ and ERa in nucleolar-related processes ${ }^{[40]}$. However, the interaction of ERa and miR-144 signaling to increase GR $\beta$ activity has not been studied. In contrast to oncogenic properties of miR-144, the loss of miR-144 expression has been shown to be related to the progression of colorectal cancer through the derepression of mTOR, a cell growth and metabolism regulator ${ }^{[41]}$. However, because the decrease in miR-144 expression leads to colorectal cancer progression, GR $\beta$ may not have an involvement. Also, miR-144 has been shown to inhibit the migration, invasion, and proliferation of carcinomas such as rectal cancer ${ }^{[42]}$ and osteosarcoma ${ }^{[43]}$, which was attributed to the downregulation of ROCK1 ${ }^{[42]}$. High levels of GR $\beta$ was shown in SaOS-2 osteosarcoma cells, which suggest that miR-144 and GR $\beta$ signaling may be differentially regulated in bone cancer. Similarly, miR-144 inhibited migration and proliferation of hepatocarcinoma cells by the downregulation of AKT3 [44] and non-squamous cell lung carcinoma through the downregulation of ZFX ${ }^{[45]}$. Due to the diverse targeting of many different genes, inhibiting the global function of miR-144 during cancer therapy could be detrimental through off-target effects, and result in the de-repression of oncogenes. The specificity of Sweet-P blocking only the interaction of miR-144 with the $3^{\prime}$ UTR of GR $\beta$ (Figure 1) to suppress cancer cell migration may be particularly useful due to the presentation of fewer side effects.

In conclusion, our discovery of Sweet-P targeting GR $\beta$ in bladder cancer sheds light on a novel drug therapy that specifically targets a gene known to cause growth, proliferation, migration, and GC hormonal therapy resistance. At this point, we have shown that the Sweet-P molecule suppresses GR $\beta$ in bladder cancer. In addition, we have shown that Sweet-P only targets GR $\beta$ and not other miR-144 regulated genes. More importantly, Sweet$P$ inhibits the ability of cancer cells to migrate. We will also be testing the effect of the Sweet-P molecule on other types of cancer. Essentially, Sweet-P may be used as a treatment option for several different carcinomas where GR $\beta$ is highly expressed including bladder, prostate, lung, or glioblastoma, as well as for liquid tumors such as in leukemia. Sweet-P can be beneficial for non-cancerous diseases also, such as asthma and GC-insensitive disease states caused by increased GR $\beta$. Thus, Sweet-P serves as the first anti-GR $\beta$ molecule that may provide a new therapy. 


\section{Acknowledgments}

This work was supported by the University of Toledo deArce-Memorial Endowment Fund (T.D.H). Research reported in this publication was also supported by the National Heart, Lung, And Blood Institute of the National Institutes of Health under Award Number K01HL125445 (T.D.H.) and L32MD009154 (T.D.H.).

\section{References}

1. McBeth L, Nwaneri AC, Grabnar M, Demeter J, Nestor-Kalinoski A, Hinds TD Jr. Glucocorticoid receptor beta increases migration of human bladder cancer cells. Oncotarget. 2016; doi: 10.18632/ oncotarget. 8430

2. Society AC. Cancer Facts \& Figures 2015. Atlanta, Ga: American Cancer Society; 2015.

3. Chamie K, Litwin MS, Bassett JC, Daskivich TJ, Lai J, Hanley JM, et al. Recurrence of high-risk bladder cancer: a population-based analysis. Cancer. 2013:3219-3227. [PubMed: 23737352]

4. Sievert KD, Amend B, Nagele U, Schilling D, Bedke J, Horstmann M, et al. Economic aspects of bladder cancer: what are the benefits and costs? World J Urol. 2009:295-300. [PubMed: 19271220]

5. Duma D, Jewell CM, Cidlowski JA. Multiple glucocorticoid receptor isoforms and mechanisms of post-translational modification. J Steroid Biochem Mol Biol. 2006:11-21. [PubMed: 17070034]

6. Kino T, Su YA, Chrousos GP. Human glucocorticoid receptor isoform beta: recent understanding of its potential implications in physiology and pathophysiology. Cell Mol Life Sci. 2009:3435-3448. [PubMed: 19633971]

7. Funder JW. Glucocorticoid and mineralocorticoid receptors: biology and clinical relevance. Annu Rev Med. 1997:231-240. [PubMed: 9046958]

8. Reichardt, H. Encyclopedic Reference of Molecular Pharmacology. Van Godewijckstraat: Springer Science and Business Media B.V; 2008. Gluco-/Mineralocorticoid Receptors; p. 543-547.

9. Dunderski J, Matic G. GLUCOCORTICOID RECEPTOR IN HEALTH AND DISEASE. Journal of Molecular Biology. 2009:248-261. [PubMed: 19358853]

10. John K, Marino JS, Sanchez ER, Hinds TD Jr. The glucocorticoid receptor: cause of or cure for obesity? Am J Physiol Endocrinol Metab. 2016:E249-257. [PubMed: 26714851]

11. Hinds TD Jr, Ramakrishnan S, Cash HA, Stechschulte LA, Heinrich G, Najjar SM, et al. Discovery of glucocorticoid receptor-beta in mice with a role in metabolism. Mol Endocrinol. 2010:17151727. [PubMed: 20660300]

12. Zanchi N, Filho M. Glucocorticoids: Extensive Physiological Actions Modulated Through Multiple Mechanisms of Gene Regulation. Cellular Physiology. 2010:311-315. [PubMed: 20940436]

13. DuBois DC, Sukumaran S, Jusko WJ, Almon RR. Evidence for a glucocorticoid receptor beta splice variant in the rat and its physiological regulation in liver. Steroids. 2013:312-320. [PubMed: 23257260]

14. Schaaf MJ, Champagne D, van Laanen IH, van Wijk DC, Meijer AH, Meijer OC, et al. Discovery of a functional glucocorticoid receptor beta-isoform in zebrafish. Endocrinology. 2008:1591-1599. [PubMed: 18096659]

15. Ledderose C, Mohnle P, Limbeck E, Schutz S, Weis F, Rink J, et al. Corticosteroid resistance in sepsis is influenced by microRNA-124--induced downregulation of glucocorticoid receptor-alpha. Crit Care Med. 2012:2745-2753. [PubMed: 22846781]

16. Bamberger CM, Bamberger AM, de Castro M, Chrousos GP. Glucocorticoid receptor beta, a potential endogenous inhibitor of glucocorticoid action in humans. J Clin Invest. 1995:2435-2441. [PubMed: 7769088]

17. Yudt MR, Jewell CM, Bienstock RJ, Cidlowski JA. Molecular origins for the dominant negative function of human glucocorticoid receptor beta. Mol Cell Biol. 2003:4319-4330. [PubMed: 12773573]

18. Lewis-Tuffin LJ, Cidlowski JA. The physiology of human glucocorticoid receptor beta (hGRbeta) and glucocorticoid resistance. Ann N Y Acad Sci. 2006:1-9. [PubMed: 16855130] 
19. Hinds TD, John K, McBeth L, Trabbic CJ, Sanchez ER. Timcodar (VX-853) Is a Non-FKBP12 Binding Macrolide Derivative That Inhibits PPAR $\gamma$ and Suppresses Adipogenesis. PPAR Research. 2016:1-10.

20. Hinds TD, Peck B, Shek E, Stroup S, Hinson J, Arthur S, et al. Overexpression of Glucocorticoid Receptor beta Enhances Myogenesis and Reduces Catabolic Gene Expression. Int J Mol Sci. 2016

21. Stechschulte LA, Wuescher L, Marino JS, Hill JW, Eng C, Hinds TD Jr. Glucocorticoid receptor beta stimulates Akt1 growth pathway by attenuation of PTEN. J Biol Chem. 2014:17885-17894. [PubMed: 24817119]

22. Longui CA, Vottero A, Adamson PC, Cole DE, Kino T, Monte O, et al. Low glucocorticoid receptor alpha/beta ratio in T-cell lymphoblastic leukemia. Horm Metab Res. 2000:401-406. [PubMed: 11069204]

23. Wang Q, Lu PH, Shi ZF, Xu YJ, Xiang J, Wang YX, et al. Glucocorticoid Receptor beta Acts as a Co-activator of T-Cell Factor 4 and Enhances Glioma Cell Proliferation. Mol Neurobiol. 2015:1106-1118. [PubMed: 25301232]

24. Avgeris M, Mavridis K, Tokas T, Stravodimos K, Fragoulis EG, Scorilas A. Uncovering the clinical utility of miR-143, miR-145 and miR-224 for predicting the survival of bladder cancer patients following treatment. Carcinogenesis. 2015:528-537. [PubMed: 25804644]

25. Yin Y, Zhang X, Li Z, Deng L, Jiao G, Zhang B, et al. Glucocorticoid receptor beta regulates injury-mediated astrocyte activation and contributes to glioma pathogenesis via modulation of beta-catenin/TCF transcriptional activity. Neurobiol Dis. 2013

26. Ligr M, Li Y, Logan SK, Taneja S, Melamed J, Lepor H, et al. Mifepristone inhibits GRbeta coupled prostate cancer cell proliferation. J Urol. 2012:981-988. [PubMed: 22819113]

27. Goecke IA, Alvarez C, Henriquez J, Salas K, Molina ML, Ferreira A, et al. Methotrexate regulates the expression of glucocorticoid receptor alpha and beta isoforms in normal human peripheral mononuclear cells and human lymphocyte cell lines in vitro. Mol Immunol. 2007:2115-2123. [PubMed: 17118450]

28. Piotrowska H, Jagodzinski PP. Trichostatin A, sodium butyrate, and 5-aza-2'-deoxycytidine alter the expression of glucocorticoid receptor alpha and beta isoforms in Hut-78 T- and Raji Blymphoma cell lines. Biomed Pharmacother. 2007:451-454. [PubMed: 17498915]

29. Piotrowska H, Jagodzinski PP. Glucocorticoid receptor alpha and beta variant expression is associated with ASF/SF2 splicing factor upregulation in HT-29 colon cancer and MCF-7 breast carcinoma cells. Arch Med Res. 2009:156-162. [PubMed: 19427965]

30. Reichardt HM, Umland T, Bauer A, Kretz O, Schutz G. Mice with an increased glucocorticoid receptor gene dosage show enhanced resistance to stress and endotoxic shock. Molecular and Cellular Biology. 2000:9009-9017. [PubMed: 11073999]

31. Christodoulopoulos P, Leung DY, Elliott MW, Hogg JC, Muro S, Toda M, et al. Increased number of glucocorticoid receptor-beta-expressing cells in the airways in fatal asthma. J Allergy Clin Immunol. 2000:479-484. [PubMed: 10984367]

32. Goleva E, Li LB, Eves PT, Strand MJ, Martin RJ, Leung DY. Increased glucocorticoid receptor beta alters steroid response in glucocorticoid-insensitive asthma. Am J Respir Crit Care Med. 2006:607-616. [PubMed: 16387802]

33. Hamid QA, Wenzel SE, Hauk PJ, Tsicopoulos A, Wallaert B, Lafitte JJ, et al. Increased glucocorticoid receptor beta in airway cells of glucocorticoid-insensitive asthma. Am J Respir Crit Care Med. 1999:1600-1604. [PubMed: 10228133]

34. Sousa AR, Lane SJ, Cidlowski JA, Staynov DZ, Lee TH. Glucocorticoid resistance in asthma is associated with elevated in vivo expression of the glucocorticoid receptor beta-isoform. J Allergy Clin Immunol. 2000:943-950. [PubMed: 10808175]

35. Cheng C, Li W, Zhang Z, Yoshimura S, Hao Q, Zhang C, et al. MicroRNA-144 is regulated by activator protein-1 (AP-1) and decreases expression of Alzheimer disease-related a disintegrin and metalloprotease 10 (ADAM10). J Biol Chem. 2013:13748-13761. [PubMed: 23546882]

36. Kim M, Tan YS, Cheng WC, Kingsbury TJ, Heimfeld S, Civin CI. MIR144 and MIR451 regulate human erythropoiesis via RAB14. Br J Haematol. 2015:583-597. [PubMed: 25312678] 
37. Zhang LY, Ho-Fun Lee V, Wong AM, Kwong DL, Zhu YH, Dong SS, et al. MicroRNA-144 promotes cell proliferation, migration and invasion in nasopharyngeal carcinoma through repression of PTEN. Carcinogenesis. 2013:454-463. [PubMed: 23125220]

38. Psarra AM, Solakidi S, Trougakos IP, Margaritis LH, Spyrou G, Sekeris CE. Glucocorticoid receptor isoforms in human hepatocarcinoma HepG2 and SaOS-2 osteosarcoma cells: presence of glucocorticoid receptor alpha in mitochondria and of glucocorticoid receptor beta in nucleoli. Int $\mathrm{J}$ Biochem Cell Biol. 2005:2544-2558. [PubMed: 16076561]

39. Vivacqua A, De Marco P, Santolla MF, Cirillo F, Pellegrino M, Panno ML, et al. Estrogenic gper signaling regulates mir144 expression in cancer cells and cancer-associated fibroblasts (cafs). Oncotarget. 2015:16573-16587. [PubMed: 26030000]

40. Solakidi S, Psarra AM, Sekeris CE. Differential distribution of glucocorticoid and estrogen receptor isoforms: localization of GRbeta and ERalpha in nucleoli and GRalpha and ERbeta in the mitochondria of human osteosarcoma SaOS-2 and hepatocarcinoma HepG2 cell lines. J Musculoskelet Neuronal Interact. 2007:240-245. [PubMed: 17947807]

41. Iwaya T, Yokobori T, Nishida N, Kogo R, Sudo T, Tanaka F, et al. Downregulation of miR-144 is associated with colorectal cancer progression via activation of mTOR signaling pathway. Carcinogenesis. 2012:2391-2397. [PubMed: 22983984]

42. Cai SD, Chen JS, Xi ZW, Zhang LJ, Niu ML, Gao ZY. MicroRNA144 inhibits migration and proliferation in rectal cancer by downregulating ROCK1. Mol Med Rep. 2015:7396-7402. [PubMed: 26458302]

43. Huang J, Shi Y, Li H, Yang M, Liu G. MicroRNA-144 acts as a tumor suppressor by targeting Rhoassociated coiled-coil containing protein kinase 1 in osteosarcoma cells. Mol Med Rep. 2015:4554-4559. [PubMed: 26081423]

44. Ma Y, She XG, Ming YZ, Wan QQ, Ye QF. MicroRNA144 suppresses tumorigenesis of hepatocellular carcinoma by targeting AKT3. Mol Med Rep. 2015:1378-1383. [PubMed: 25370363]

45. Zha W, Cao L, Shen Y, Huang M. Roles of Mir-144-ZFX pathway in growth regulation of nonsmall-cell lung cancer. PLoS One. 2013:e74175. [PubMed: 24066116] 


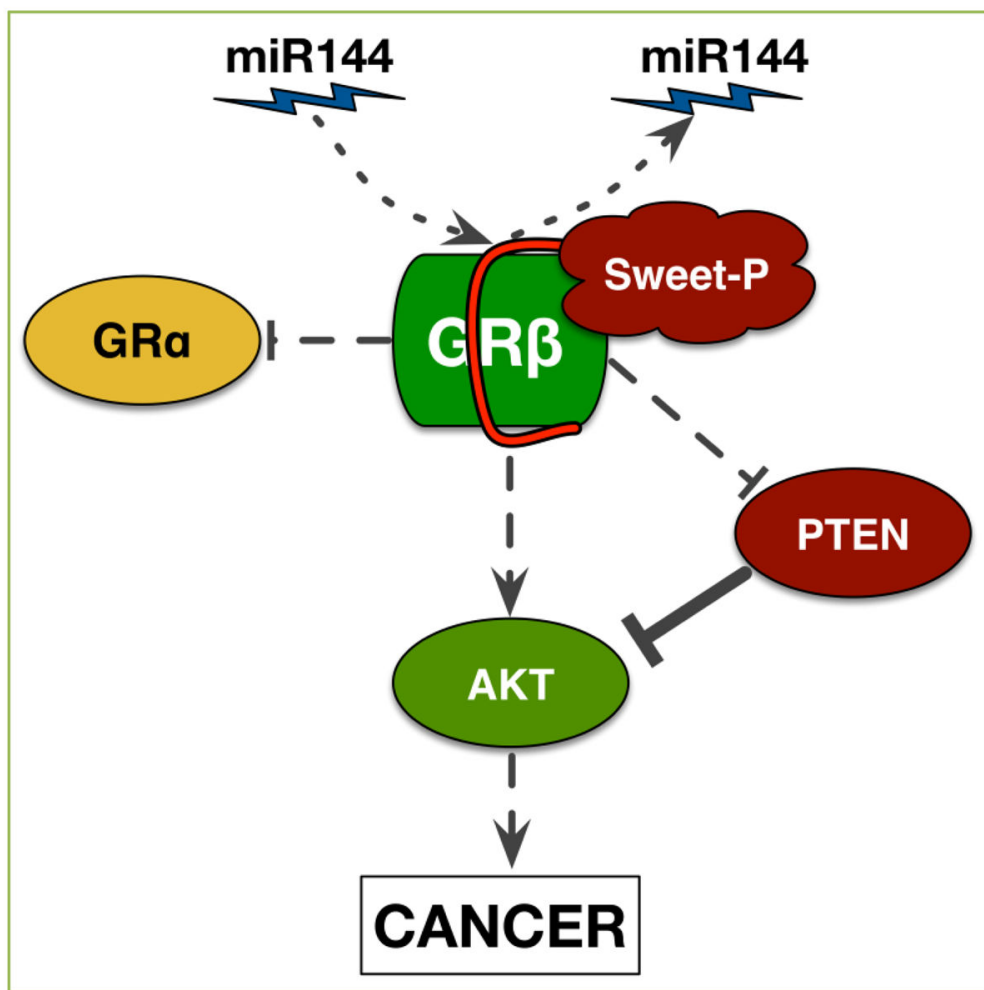

Figure 1. Sweet-P inhibition of GR $\beta$ reduces signaling that leads to cancer Sweet-P inhibits miR144 binding to the $3^{\prime}$ UTR of human GR $\beta$, resulting in reduced expression. Sweet-P inhibition of GR $\beta$ increases GRa and PTEN activity and decreases AKT, which leads to reduced cancer growth and migration. 